\title{
Epistemological Implications of Relativism
}

\author{
J. Adam Carter \\ University of Edinburgh
}

\begin{abstract}
Relativists about knowledge ascriptions think that whether a particular use of a knowledge-ascribing sentence, e.g., "Keith knows that the bank is open" is true depends on the epistemic standards at play in the assessor's context-viz., the context in which the knowledge ascription is being assessed for truth or falsity. Given that the very same knowledge-ascription can be assessed for truth or falsity from indefinitely many perspectives, relativism has a striking consequence. When I ascribe knowledge to someone (e.g., when I say that, at a particular time, "Keith knows that the bank is open"), what I've said does not get a truth-value absolutely, but only relatively. If this semantic thesis about the word "knows" and its cognates is true, what implications would this have for epistemology, the philosophical theory of knowledge? The present aim will be to engage with this mostly unexplored question, and then to consider how the epistemological conclusions drawn might bear on the plausibility of a relativist semantics for "knows".
\end{abstract}

\section{Epistemic Relativism and Relativism about "Knows"}

Traditionally, the term "epistemic relativism" has been used to pick out a wide class of philosophical positions. Rorty (1979), Feyerabend (1987), Hacking (1982), and Wittgenstein (1969), to name a few, have often been branded "relativists" for maintaining that (broadly speaking) knowledge, justification, rationality, epistemic norms and the like are the products of a plurality of conventions and frameworks of assessment and that their authority does not extend beyond the contexts giving rise to them. ${ }^{1}$ One very natural way of glossing what it is an epistemic relativist wants to say is that-in short-knowledge, just like other epistemic standings, depends always on context. There is no way, as Rorty (1989) put it, to "escape" the various contingencies of the knowledge-ascribing situations in which we find ourselves, no "neutral standpoint" of epistemic evaluation.

${ }^{1}$ See Baghramian and Carter $(2015 \$ 1)$. For some recent overviews of various forms of epistemic relativism, see Baghramian (2004), Boghossian (2006 Ch. 5-6), Carter (2016 Ch. 3-5), Kusch (2010), Seidel (2014) and Siegel (2013). 
However, this quick gloss should be initially perplexing: epistemological contextualists also fly under the banner that knowledge depends always on context (albeit, contexts of a specific sort). Contextualists after all think that whether any given knowledge-ascribing sentence (e.g., "Keith knows that the bank is open") is true depends on the speaker's context ${ }^{2}$ by depending on the epistemic standards at play when the speaker is using a knowledge-ascribing sentence. Contextualism is more or less mainstream in contemporary epistemology. But isn't epistemic relativism supposed to be radical?

Given that contextualists, like traditional epistemic relativists, embrace the dictum (generally construed) that knowledge depends always on context, is contextualism best understood as a particular version of relativism? Or, alternatively, are traditional construals of "epistemic relativism" perhaps not as radical or iconoclastic as we've been inclined to think?

According to John MacFarlane (2014), it's the latter that is the case ${ }^{3}$. Philosophically interesting relativism must go a crucial step further than many of the disparate views that have been branded "epistemic relativism" have gone ${ }^{4}$. To appreciate why he thinks so, consider the following two example sentences. (1) is a reference point in the contextualist literature. (2) is a reference point in the (traditional) relativist literature.

(1). "Keith knows that the bank is open."

(2). "Galileo knows that the earth revolves around the sun."

Contextualists (e.g., DeRose (1992); DeRose (2009)) insist that the extension of "knows" in (1) varies with the context in which (1) is used, and accordingly (1) can express different propositions and have different truth-conditions in different contexts (of use) $)^{5}$. For instance, if I utter "Keith knows that the bank is open" in a context where it is of dire importance whether Keith can make a withdrawal, (1) comes out true only if Keith meets very demanding epistemic requirements. And this is because, for the contextualist, what I've said when I utter (1) in a high-stakes context is something like

\footnotetext{
${ }^{2}$ And this is because, according to the (attributer) contextualist (e.g., DeRose (1992)), sentences like "Keith knows that the bank is open" can express different propositions in different conversational contexts. Cf., however, Williams (2007) for a very different kind of view under the description of "contextualism."

${ }^{3}$ See also MacFarlane (2005).

${ }^{4}$ As I note later, MacFarlane regards various views which have been traditionally regarded as "epistemic relativism" as better classified as forms of contextualism.

${ }^{5}$ Jonathan Schaffer (2004) defends a related view, contrastivism, which treats "knows" as invariably expressing a ternary relation with a slot for a contrast proposition provided by the context. Schaffer himself regards this position as a 'sibling' to contextualism, though it is sometimes regarded as form of contextualism. Cf., Brogaard (2008) for another non-standard version of contextualism about "knows" which Brogaard describes as perspectivalism.
} 
$\left(1^{\star}\right)$. Keith knows high that the bank is open.

And this is a different proposition than what I've uttered (using the same sentence) in relaxed practical circumstances, viz.,

$\left(1^{* *}\right)$. Keith knows low that the bank is open.

Likewise, for the contextualist, what goes for (1), goes for (2). I've expressed a different proposition, with different truth-conditions ${ }^{6}$, when I utter (2) in an academic context (i.e., Galileo knows low that the earth revolves around the sun) than I do when the fate of the world rides on Galileo's cognitive life (i.e., Galileo knows high $_{\text {that }}$ the earth revolves around the sun).

What does the traditional epistemic relativist say about (1) and (2)? By "traditional" epistemic relativist, I mean: the kind of "Rorty-style" epistemic relativist which has recently drawn the sustained criticism of Paul Boghossian (2006). As Boghossian sees it, the traditional epistemic relativist regards (2) as depending on context in the following way: firstly, the epistemic relativist says there are "no absolute facts" of the form (2), (i.e., $S$ knows that p.) And so, if a person S's, knowledge ascriptions are to have any prospect of being true, we must not construe his utterances of the form

"Galileo knows that the earth revolves around the sun"

as expressing the claim

Galileo knows that the earth revolves around the sun

but rather as expressing the claim.

$\left(2^{*}\right)$. According to the epistemic system $C$, that I, S, accept, Galileo knows that the earth revolves around the sun.

And, what goes for (2) goes for more mundane knowledge ascriptions, such as (1), which Boghossian's epistemic relativist tells us expresses the explicitly relational proposition:

$\left(1^{* * *}\right)$. According to the epistemic system $C$, that I, S, accept, Keith knows that the bank is open.

${ }^{6}$ For an introduction to truth-conditional semantics, see Heim and Kratzer (1998 \$1). 
Putting this all together, DeRose and Rorty can thus agree that statements like (1) and (2) do not get a truth value, simpliciter, but only relative to a standards parameter whose value is supplied by the context in which (1) and (2) are used. In this respect, the views are equally radical, or equally unradical.

Moreover-and this is a point MacFarlane stresses-both the contextualist and the traditional epistemic relativist embrace the following thesis with respect to utterance tokens of (1) and (2):

Knowledge Ascription Absolutism: Utterance tokens of knowledge-ascribing sentences have their truth values absolutely ${ }^{7}$.

As MacFarlane sees it, an epistemic relativist of a philosophically interesting ${ }^{8}$ sort is going to do more than merely insist that knowledge depends always on context, but also, to go a step further: to reject Knowledge Ascription Absolutism.

MacFarlane's semantics for "knows," which gives what he calls a context of assessment a semantically significant role, takes this further step and denies Knowledge Ascription Absolutism.

\section{New Epistemic Relativism}

This section briefly outlines the key features of "new" epistemic relativism (along the lines sketched by MacFarlane ${ }^{9}$ ), after which the implications for this view in epistemological theory will be canvassed.

First some terminology. Following MacFarlane $(2014,60)$ we can distinguish a context of assessment from the more familiar notion of a context of use in the following way:

Context of use: a possible situation in which a sentence might be used and where the agent of the context is the user of the sentence.

${ }^{7}$ Knowledge Ascription Absolutism could just as easily be framed in terms of sentence truth. On MacFarlane's view, the kind of relativism that parts ways interestingly from absolutism can be expressed either in terms of sentence truth (following the semantic framework of Lewis (1980)) or in terms of propositional truth (following the semantic framework of Kaplan (1989)). As Wright $(2007,262)$ notes, a familiar way to capture the kind of relativism MacFarlane is in terms of utterance tokens, understood as "an actual historic voicing or inscription of a sentence of a certain type" $(2007,262)$.

${ }^{8}$ Indeed, as MacFarlane (2014, 33, fn. 5) sees it, the view which Paul Boghossian (2006) recently (and influentially) challenged, at length, under the description of "epistemic relativism" isn't really that interesting. It was really a form of contextualism, modeled on Gilbert Harman's (1975) moral relativism which was itself, according to MacFarlane, a kind of contextualism.

${ }^{9}$ For some similar relativist treatments of "knows," see Richard (2004). Cf. Kompa (2002) for an earlier example of a similar view, though one which might be aligned more closely with non-indexical contextualism. I am focusing on MacFarlane's presentation of the view here as it has been developed in the most detail (e.g., 2005, 2009 and 2014) and has generated the most discussion. 
Context of assessment: a possible situation in which a use of a sentence might be assessed, where the agent of the context is the assessor of the use of a sentence (ibid., 60).

Whereas relativising knowledge-ascribing sentence truth to merely a context of use is compatible with Knowledge Ascription Absolutism, relativising knowledgeascription sentence truth to a context of assessment is not ${ }^{10}$.

On MacFarlane's view, truth-relativism of the philosophically interesting sort with respect to "knows" maintains that when I say that "Keith knows the bank is open", the truth of what I just said depends (in part) on a context of assessment-viz., this utterance token gets a truth value only once the standard of the assessor is specified. Accordingly, my claim that "Keith knows the bank is open" can be at the same time true relative to a context of assessment (e.g., in which "Bob" is evaluating my claim) where ordinary "low" standards are in place, yet false relative to a context of assessment in which "Rene" is evaluating my claim, and where Cartesian standards are in place ${ }^{11}$.

Since the same knowledge-ascription can be assessed from indefinitely many perspectives, there are only perspective-relative answers to the question whether what I say when I ascribe knowledge to someone is true ${ }^{12}$. Indeed, even holding fixed the standards operative in my context, what I say can be true relative to some assessment contexts and false relative to others. My knowledge ascription does not get its truth value absolutely ${ }^{13}$.

In three different places, MacFarlane $(2005,2011,2014)$ has defended a "master argument" for an assessment-sensitive semantics for knowledge attributions. Here is the core strand of argument he's defended on each occasion:

\section{Master Argument for Assessment Sensitive Semantics for Knowledge Attri- butions}

\footnotetext{
${ }^{10}$ See, for instance, MacFarlane (2014, pp. 49, 67, 73, fn. 3, 89, passim).

${ }^{11}$ For MacFarlane, then, the answer to the question of why contextualism, as well as Rorty-style epistemic relativism, is not on the interesting side of the relativist's line is that while the contextualist can, no less than the relativist, recognize a "standards" parameter, for the contextualist, its value will be supplied by the context of use, whereas the relativist (proper) takes it to be supplied completely independently of the context of use, by the context of assessment. See Baghramian and Carter $(2015 \$ 5)$ for an overview. See also MacFarlane (2007), MacFarlane (2012a) and MacFarlane (2012b).

${ }^{12} \mathrm{See}$, for example, MacFarlane (2012a). Independent of the specification of an assessor's standard, my claim that Keith knows that the bank is open simply lacks a truth-value much as, by comparison, an indexical expression such as "I have been to Tahiti" simply lacks a truth-value independent of contextual facts about the context of use (i.e. which pick out to whom "I" refers).

${ }^{13}$ For two accessible overview discussions of MacFarlane's view, see Baghramian and Carter (2015 $\$ 5$ ) and Carter (2016 Ch. 7).
} 
(3). Standard invariantism, contextualism and SSI all have advantages and weaknesses.

(4). Relativism preserves the advantages while avoiding the disadvantages.

(5). Therefore, prima facie, we should be relativists about knowledge attributions.

Premise (3) is more or less uncontroversial. One interesting line of question is whether, premise (4) of MacFarlane's master argument is true ${ }^{14}$. For the present purposes, though, we can set this aside.

The question that will be of interest now is: if we do have good reason to embrace a truth-relativist semantics for "knows," then how should this affect our epistemological theorising? What is the upshot for this view in epistemology-viz., that is, of giving "knows" a semantic treatment such that knowledge ascriptions do not have their truth values absolutely? This is the question to which the remainder of this disucssion will be concerned.

\section{Implications of Relativism}

\section{Equivalence and reduction}

Knowledge is the central subject matter around which epistemological theorizing is organized $^{15}$. If "knows" gets a relativist treatment, we should expect that other epistmemic notions, which are connected in various ways with knowledge, will as well. Here I'll consider epistemic notions which stand (modulo certain substantive commitments) in equivalence, reductive and normative relations (respecitvely) to "knows" and its cognates.

\begin{tabular}{ll}
\hline Other epistemic items & Relation to knowledge \\
\hline Evidence & Equivalence (E=K) \\
Knowledge-how & Reductive (Intellectualism) \\
Knowledge norms & Normative \\
\hline
\end{tabular}

\footnotetext{
${ }^{14}$ For some recent criticism on this point, see Cappelen and Hawthorne (2010), Carter (2016 Ch. 7-8), Stanley (2005 Ch. 7), and Stanley (2015). Cf., Partee (2004).

${ }^{15}$ The longstanding concern with the project of analysing propositional knowledge is a testament to this. For an overview, see Ichikawa and Steup (2014).
} 
Take, as a starting point, a very tight conceptual connection: Williamson's (2000) knowledge-evidence equivalence thesis, $E=K$, according to which "knowledge, and only knowledge, constitutes evidence ... S's evidence [is] S's knowledge, for every individual or community $S$ in any possible situation ${ }^{16}$."

$E=K$ is controversial, though the proposal has become increasingly attractive for those sympathetic with the knowledge-first approach in epistemology. Suppose one combines $E=K$ with MacFarlane-style relativism about "knows." In short, the relativist about "knows" had better be prepared to embrace the view that evidence ascriptions are assessment-sensitive, or give up $E=K$. Consider, after all, that the proponent of $E=K$ is submitting that the claim that $S$ 's evidence includes $E$ if, and only if, $S$ knows $E$ is extensionally correct in all metaphysically possible worlds ${ }^{17}$. If knowledge ascriptions are assessment-sensitive, but evidence ascriptions weren't, then, possibly, a claim of the form "S knows $E$ " could be true as uttered at $c_{1}$ and assessed from $c_{2}$, even when " $S$ 's evidence includes $E$ " is false as uttered at $c_{2}$ and assessed at $c_{2}$, a result that stands in tension with the $E=K$ proponent's commitment to regarding the claim that $S$ 's evidence includes $E$ if, and only if, $S$ knows $E$ as extensionally correct in all metaphysically possible worlds.

The epistemological "bleedover" from an assessment-sensitive semantics for "knows" to other epistemic notions connected to knowledge isn't limited to equivalence relations. Let's consider now a reductive relation, one embraced by intellectualists about knowledge-how ${ }^{18}$.

Gilbert Ryle's (1945) distinction between knowing-how and knowing-that had for decades been taken for granted. But this is no longer so. Intellectualists about knowing-how, following Stanley and Williamson (2001), insist that knowing how to do something is a species of propositional knowledge-viz., that knowing-how is a kind of knowing-that ${ }^{19}$. As Stanley (2011) puts the core intellectualist insight:

[...] you know how to ride a bicycle if and only if you know in what way you could ride a bicycle. But you know in what way you could ride a bicycle if and only if you possess some propositional knowledge, viz. knowing, of a certain way $w$ which is a way in which you could ride a bicycle, that $\mathrm{w}$ is a way in which you could ride a bicycle $(2001,209)$.

Intellectualism isn't for everyone ${ }^{20}$. But let's consider: what is the state of play for philosophers who embrace intellectualism about knowledge-how as well as an

${ }^{16}$ Williamson $(2000,183)$. See also Williamson (1997).

${ }^{17}$ Compare: Ichikawa and Steup (2014), who make a similar point regarding the commitments of proponents of $\mathrm{K}=\mathrm{JTB}$.

${ }^{18}$ Stanley and Williamson (2001); Stanley (2011a).

${ }^{19}$ Stanley (2011b, 207); Stanley (2011a, 122), passim.

${ }^{20}$ For a sample of some recent criticisms of intellectualism, see Noë (2005), Toribio (2008), Cath 
assessment-sensitive semantics for propositional knowledge ascriptions? Again, in short: it is hard to see knowledge-how ascriptions would not be assessment-sensitive, too. Suppose, for reductio, that knowing how to do something is just a kind of propositional knowledge and that the truth-conditions for knowing how to do something (e.g., as in the case of attributions of the form "Irina knows how to perform a salchow") are not assessment sensitive, but the truth-conditions for proposition knowledge are. So we can suppose that "Irina knows that $p$ " has assessment-sensitive truth conditions, where $p$ is a proposition specifying a way, $w$, which is a way in which Irina could perform a salchow, that $w$ is a way in which Irina could perform a salchow. This would be perplexing to say the least. One way to make this point is in terms of absolute truth values. If I antecedently embrace intellectualism and assert "Irina knows how to perform a salchow" I regard myself as having said something that is true if and only if Irina knows some proposition. If my ascription to Irina of knowledge of that proposition does not get an absolute truth value, then it's puzzling to see how my knowledge-how ascription to Irina would. Thus, for intellectualists about knowledge-how, no less than proponents of $\mathrm{E}=\mathrm{K}$, it looks like a MacFarlane-style semantics for "knows" generates further epistemological commitments.

\section{Normativity and value}

I've suggested elsewhere that similar arguments can be made in the case of reductive accounts of understanding-why, and even (though perhaps more controversially) for certain accounts of epistemic justification ${ }^{21}$. I want to now consider the implications for an assessment-sensitive semantics for "knows" within the context of epistemological debates about epistemic norms and epistemic value. Let's begin with norms.

Here are two which are popular nowadays: the knowledge norms of assertion and action.

"One must: assert that p only if one knows p" (Williamson 2000, 243).

"Treat the proposition that $\mathrm{p}$ as a reason for acting only if you know that p" (Hawthorne and Stanley 2008, 578).

(2011); Poston (2009); Carter and Pritchard (2015a); Carter and Pritchard (2015b); Carter and Pritchard (Forthcoming). For an idiosyncratic version of intellectualism which embraces that knowing how to do something is in virtue of propositional attitudes, but which does not embrace propositionalism, the thesis that knowledge-how is a propositional knowledge relation, see Bengson and Moffet (2011).

${ }^{21}$ See Carter (2014) for the argument that a MacFarlane-style semantics for "knows" must be paired (for the reductivist about understanding-why) with an assessment-sensitive semantics for understanding-why ascriptions. I also, in Carter (2016 Ch. 8), make a more detailed argument for why a relativist treatment of "knows" has a range of other implications in epistemology, beyond some of the highlights I'm able to cover here. 
If we assume ex ante MacFarlane's semantics for "knows," then proponents of the knowledge norms for action and assertion face an interesting position: they will be forced to embrace a view we can call normative non-absolutism with respect to assertion and action.

Call normative absolutism the view that a particular speech act, at a particular time, has its normative properties absolutely. For example, if I violate the norm governing permissible assertion by asserting $a$ at $t_{1}$, then (on normative absolutism) it's not the case that, at $t_{2}$, my utterance token $a$ can "no longer have violated" the norm of assertion at $t_{1}$. And vice versa.

Denying normative absolutism has its costs. As Gareth Evans (1985) puts the point:

Just as we use the terms 'good' and 'bad', 'obligatory' and 'permitted' to make an assessment, once and for all, of non-linguistic actions, so we use the term 'correct' to make a once-and-for-all assessment of speech acts .... if a theory of reference permits a subject to deduce merely that a particular utterance is now correct but later will be incorrect, it cannot assist the subject in deciding what to say, nor in interpreting the remarks of others.

If "knows" gets a relativist treatment, then-at least in so far as we are inclined to embrace the knowledge norm of assertion-there can be no assessment, once and for all, of assertions ${ }^{22}$. And what goes for the knowledge norm of assertion goes for knowledge norms of action as well as belief, practical reasoning and the like. In each case, one can embrace such a knowledge norm, alongside a relativist treatment for "knows" only by giving up normative absolutism.

While knowledge norms are often embraced by those sympathetic to the knowledgefirst approach, a more general axiological insight about knowledge is embraced even more widely ${ }^{23}$. The idea is, put crudely, that knowledge is more epistemically valuable than mere true opinion. Call this the value insight. As Duncan Pritchard (2009, 19) puts it, if we didn't take something like the value insight for granted in epistemology,

\footnotetext{
${ }^{22}$ While a stock objection to truth-relativist semantics, more generally, is that an implication is that assertions are not once-and-for all assessable, the typical sort of relativist response doesn't have purchase against the tension just described between a relativist treatment for "knows" and the knowledge norm of assertion, specifically. For instance, in response to Evans' challenge, MacFarlane embraces a kind of "meet the challenge" norm for assertion which he thinks preserves the integrity of assertion. See MacFarlane (2003). Cf., Kölbel $(2004,308)$. However, redeploying this kind of move is an option only if one isn't already committed to a particular norm of assertion. So, for one who antecedently embraces the knowledge norm of assertion, a truth-relativist semantics for "knows" is going to have, as a consequence, normative non-absolutism in the case of assertion.

${ }^{23}$ Cf., Kvanvig (2003) for criticism.
} 
"then it would be simply mysterious why knowledge has been the focus of so much of epistemological theorising, rather than some other epistemic standing like justified true belief."

One interesting implication a relativist treatment of "knows" would have, for epistemological theorizing, is that it's not clear how the value insight can continue to be maintained. The insight, unpacked more carefully, is that for any given proposition, it's better (from a purely epistemic or intellectual point of view) to know that proposition than to merely truly believe the proposition but fail to know it ${ }^{24}$.

Suppose A says "Keith knows that the bank is open." The value insight implies that if this claim is true, then the state of affairs in virtue of which it is true is more epistemically valuable than is the state of affairs of Keith's merely truly believing that the bank is open, but not knowing this. A relativist semantics for "knows" implies that, since the truth of what $A$ just said about Keith's mental life can be assessed from indefinitely many perspectives, there are only perspective-relative answers to the question whether the state of affairs characterizing Keith's mental life is more valuable than were Keith to merely truly belief that the bank was open.

\section{New Relativism: Wider Epistemological Implications}

The previous section outlined several specific ways in which a relativist semantics for "knows" would have some consequences, more broadly, in epistemological theory. I want to close by gesturing to a bigger-picture issue.

Compare epistemology with paleontology, which studies life prior to the Holocene epoch, primarily by scientifically studying the fossil record. Paleontology is organized around certain rules about how inferences are best drawn to conclusions about ancient life. If paleontologists began playing by very different rules-suppose they began relying on tea leaves more so than the fossil record-paleontology would no longer be valuable in telling us with accuracy about ancient life. The value of the practice, in light of these new rules, wouldn't sustain the practice.

In recent work, John Turri (Forthcoming) argues that a rule normatively sustains a practice when the value achieved by following the rule explains why agents continue following that rule, thus establishing and sustaining a pattern of activity.

The practice of epistemology, or epistemological inquiry is, like paleontology, also organized around certain rules - the rules which epistemologists take for granted when engaging in typical first-order debates. Imagine the nearest world where epistemologists (replete with their dispositions to do epistemology as usual) wake up to find themselves convinced by arguments for a relativist semantics for "knows." Epistemol-

\footnotetext{
${ }^{24}$ For discussion on this point, see Carter, Jarvis, and Rubin (2013).
} 
ogists, having woken up with this revelation, accordingly reject Knowledge Ascription Absolutism. Suddenly, the rules change dramatically.

There would be no point, for example, in continuing to follow one of the most basic rules which sustains the practice of epistemology: that universal generalizations about knowledge stand to be legitimitely challenged by pointing to imagined knowledge cases. There is, as Williamson $(2007,180)$ puts it, a kind of "cognitive weight analytic philosophers rest on thought experiments." And analytic epistemology is a paradigmatic example of an area in analytic philosophy where thought experiments are relied upon ${ }^{25}$.

But epistemologists, having woken with commitments to rejecting Knowledge Ascription Absolutism, would have little reason to continue playing by such rules anymore. For example, even if most individuals agree that, within a given thought experiment $T$, a subject $S$ 's claim that Keith knows that the bank is open is true, this could not in itself constitute evidence one way or another for whether Keith really knows that the bank is open. After all, given that the relativist semantics for "knows" rejects Knowledge Ascription Absolutism, this isn't the sort of thing for which individuals' willingness to attribute knowledge would be evidence. At any rate, there would be no reason to rest much (as Williamson says) "cognitive weight" on what individuals say about such cases like $T$, to the end of theorizing about the nature of knowledge.

Putting this all together: if we were to suppose that epistemologists embraced MacFarlane's semantics for "knows," we should expect them to find little point in carrying on by following the same rules. The "new rules" would not normatively sustain, in Turri's sense, the practice of theorizing about knowledge in the way epistemologists traditionally have.

Trivially, the current rules do normatively sustain the practice. The theoretical value achieved by following the rules characteristic of epistemology plausibly explains why epistemologists continue to pursue traditional projects. Some practices are more valuable than others. To the extent that the practice of epistemology (along traditional lines) is a valuable one-replete with the kind of rules epistemologists take for granted in practice-we have either (i) prima facie reason to be skeptical that a relativist semantics for "knows" is tractable; or, alternatively, (ii) prima facie reason to be skeptical that our theory of knowledge attributions should inform the epistemologist's theory of knowledge ${ }^{26} .7$

\footnotetext{
${ }^{25}$ This point is perhaps on clearest display in the post-Gettier literature. See here Shope (1983) for a review.

${ }^{26}$ For an argument in favour of this kind of conclusion, see Hazlett (2010). Cf. Carter (2016 Ch. $8-9)$.

${ }^{27}$ Thanks to Jonathan Jenkins Ichikawa and Brian Rabern for helpful comments.
} 


\section{References}

Baghramian, Maria. 2004. Relativism. Routledge.

Baghramian, Maria, and J. Adam Carter. 2015. "Relativism." In Stanford Encyclopaedia of Philosophy, edited by Edward N. Zalta, Fall 2015, 1-46. http://plato . stanford. edu/entries/relativism/.

Bengson, John, and Marc Moffet. 2011. "Nonpropositional Intellectualism." In Knowing How: Essays on Knowledge, Mind, and Action, edited by John Bengson and Marc Moffet, 161-95. Oxford: Oxford University Press.

Boghossian, Paul. 2006. Fear of Knowledge: Against Relativism and Constructivism. Oxford University Press.

Brogaard, Berit. 2008. "In Defence of a Perspectival Semantics for 'Know." Australasian Journal of Philosophy 86 (3): 439-59.

Cappelen, Herman, and John Hawthorne. 2010. Relativism and Monadic Truth. Oxford: Oxford University Press.

Carter, J. Adam. 2014. "Relativism, Knowledge and Understanding." Episteme 11 (1): $35-52$.

-_-. 2016. Metaepistemology and Relativism. London: Palgrave Macmillan.

Carter, J. Adam, and Duncan Pritchard. 2015a. "Knowledge-How and Epistemic Luck." Noûs 49 (3): 440-53.

- - 2015b. "Knowledge-How and Cognitive Achievement." Philosophy and Phenomenological Research 91 (1): 181-99.

- - . Forthcoming. "Knowledge-How and Epistemic Value." Australasian Journal of Philosophy.

Carter, J. Adam, Benjamin Jarvis, and Katherine Rubin. 2013. "Knowledge and the Value of Cognitive Ability." Synthese 190 (17): 3715-29.

Cath, Yuri. 2011. "Knowing-How Without Knowing-That." In Knowing How: Essays on Knowledge, Mind and Knowing How: Essays on Knowledge, Mind and Action, edited by John Bengson and Marc Moffett, 113-35. Oxford: Oxford University Press.

DeRose, Keith. 1992. "Contextualism and Knowledge Attributions." Philosophy and Phenomenological Research. JSTOR, 913-29. 
-- 2009. The Case for Contextualism: Knowledge, Skepticism, and Context, Vol. 1: Knowledge, Skepticism, and Context. Vol. 1. Oxford University Press.

Evans, Gareth. 1985. "Does Tense Logic Rest on a Mistake?" In Collected Papers: Gareth Evans, edited by Gareth Evans, 346-63. Oxford: Clarendon Press.

Feyerabend, Paul. 1987. Farewell to Reason. London: Verso.

Hacking, Ian. 1982. "Language, Truth and Reason." In Rationality and Relativism, 48-66.

Hawthorne, John, and Jason Stanley. 2008. "Knowledge and Action." Journal of Philosophy 105 (10): 571-90.

Hazlett, Allan. 2010. "The Myth of Factive Verbs." Philosophy and Phenomenological Research 80 (3): 497-522.

Heim, Irene, and Angelika Kratzer. 1998. Semantics in Generative Grammar. London: Blackwell.

Ichikawa, Jonathan Jenkins, and Matthias Steup. 2014. "The Analysis of Knowledge." In The Stanford Encyclopedia of Philosophy, edited by Edward N. Zalta, Spring 2014. http://plato.stanford.edu/archives/spr2014/entries/knowledge-analysis/.

Kompa, Nikola. 2002. "The Context Sensitivity of Knowledge Ascriptions." Grazer Philosophische Studien 64 (1): 1-18.

Kölbel, Max. 2004. "Faultless Disagreement." In Proceedings of the Aristotelian Society (Hardback), 104:53-73. 1. Wiley Online Library.

Kusch, Martin. 2010. “Epistemic Replacement Relativism Defended." In EPSA Epistemology and Methodology of Science: Launch of the European Philosophy of Science Association, edited by Mauricio Suarez, 165-75.

Kvanvig, Jonathan L. 2003. The Value of Knowledge and the Pursuit of Understanding. Cambridge University Press.

MacFarlane, John. 2003. "Future Contingents and Relative Truth." Philosophical Quarterly 53 (212): 321-36.

- - . 2005. "Making Sense of Relative Truth." In Proceedings of the Aristotelian Society, 105:305-23. 1. Wiley Online Library.

- - . 2007. "Relativism and Disagreement." Philosophical Studies 132 (1). Springer: $17-31$. 
- - 2012a. "Relativism and Knowledge Attributions." In The Routledge Companion to Epistemology, edited by Duncan Pritchard and Sven Bernecker, 536-544. London: Routledge.

- - . 2012 b. "Relativism." In The Routledge Companion to Philosophy of Language, edited by Delia Graff Fara and Gillian Russell. London: Routledge.

- - . 2014. Assessment Sensitivity: Relative Truth and Its Applications. Oxford University Press.

Noë, Alva. 2005. "Against Intellectualism.” Analysis 65: 278-90.

Partee, Barbara. 2004. “Comments on Jason Stanley's 'on the Linguistic Basis for Contextualism." Philosophical Studies 119: 147-59.

Poston, Ted. 2009. "Know-How to Be Gettiered?" Philosophy and Phenomenological Research 79 (3): 743-47.

Pritchard, Duncan. 2009. "Knolwedge, Understanding and Epistemic Value." Royal Institute of Philosophy Supplement 64: 19-43.

Richard, Mark. 2004. “Contextualism and Relativism." Philosophical Studies 119 (1): $215-42$.

Rorty, Richard. 1979. Philosophy and the Mirror of Nature. Princeton, N.J.: Princeton University Press.

- - . 1989. Contingency, Irony and Solidarity. Cambridge: Cambridge Univeristy Press.

Ryle, Gilbert. 1945. "Knowing How and Knowing That: The Presidential Address.” In Proceedings of the Aristotelian Society, 1-16. JSTOR.

Schaffer, Jonathan. 2004. "From Contextualism to Contrastivism." Philosophical Studies 119 (1): 73-103.

Seidel, Markus. 2014. Epistemic Relativism: A Constructive Critique. London: Palgrave Macmillan.

Shope, Robert K. 1983. An Analysis of Knowing: A Decade of Research. Princeton: Princeton University Press.

Siegel, Harvey. 2013. Relativism Refuted. Springer.

Stanley, Jason. 2005. Knowledge and Practical Interests. Oxford University Press. 
- - . 2011a. Know How. Oxford University Press.

- - . 2011b. "Knowing (How)." Noûs 45 (2): 207-38.

- - . 2015. "On the Case for Truth-Relativism." Philosophy and Phenomenological Research.

Stanley, Jason, and Timothy Williamson. 2001. "Knowing How." Journal of Philosophy 98: 411-44.

Toribio, Josefa. 2008. “How Do We Know How?” Philosophical Explorations 11 (1): $39-52$.

Turri, John. Forthcoming. "Sustaining Rules: A Model and Application." In Knolwedge First: Approaches in Epistemology and Mind, edited by J. Adam Carter, Emma C. Gordon, and Benjamin Jarvis. Oxford: Oxford University Press.

Williams, Michael. 2007. "Why (Wittgensteinian) Contextualism Is Not Relativism." Episteme 4 (01). Cambridge Univ Press: 93-114.

Williamson, Timothy. 1997. "Knowledge as Evidence." Mind 106 (424): 717-41.

- - 2000. Knowledge and Its Limits. Oxford University Press.

- - . 2007. The Philosophy of Philosophy. Oxford: Oxford University Press.

Wittgenstein, Ludwig. 1969. On Certainty. Blackwell Oxford.

Wright, Crispin. 2007. "New Age Relativism and Epistemic Possibility: The Question of Evidence." Philosophical Issues 17 (1): 262-83. 